\title{
편집인의 글
}

김철환

대한금연학회 간행이사, 인제대학원대학교 보건경영학과 교수

대한금연학회가 2008년 11월 창립된 때부터 고유의 학술 지를 발간하기로 한 것은 매우 중대한 결심이었다. 왜냐하면 학회를 만들고 운영하고 학회지를 만들어본 사람은 그 일에 얼마나 많은 인력과 재정과 시간이 드는지 알기 때문이다. 최근 대학교수의 업적 평가가 강화되면서 학술진흥재단 등 재지가 되기 위해서는 최소 3 년이 걸리는 신생 학회지는 좋 은 논문을 투고받는 것이 더욱 힘들어졌다. 이런 사실을 잘 아는 맹광호 학회장 이하 여러 부회장과 이사들이 학회지 창 간과 함께 이에 필요한 예산을 쓰도록 결의한 것은 매우 큰 결단인 것이다.

간행위윈회가 꾸려지고 투고 규정을 만들고 (주)인포랑 과 협의하여 전자심사시스템을 구축하였다. 그리고 여러 연 구자들에게 논문 투고를 요청한 후 심사시스템을 통해 심사 위원들이 심사하고 수정과 재심사를 반복하여 5 편의 연구 논문을 싣게 되었다.

금연 연구 분야는 종합적인 접근이 아니면 문제 해결이 어 려운 분야이므로 다학제 간의 정보 교환과 협동이 매우 중요 하다. 그런 의미에서 이번 창간호에 다양한 연구자들이 투고 한 것은 다행스러운 일이다. 정부 산하 기관에서 금연 분야 의 사업을 총괄하는 한국보건사회연구원의 최은진 박사가
금연 정책에 대한 종설 및 $\mathrm{FCTC}$ 의 의미와 최근 동향까지 정 리해 주었다. 그 외에도 가정의학, 정신의학, 간호학 등 여러 분야에서 연구 논문을 제출하였다. 이번 호에는 이언숙 등이 금연의 비약물 요법을 심도 있게 리뷰해 주었고, 신차수 등 은 여자 간호대학생의 흡연 관련 요인으로 가장 중요한 것은 흡연자 친구수와 흡연 인식임을 밝히는 연구 논문을 제출하 였다. 김옥길 등은 택시기사의 흡연은 구조적인 사회경제적 요인에 의한 설명력이 더 높았음을 보고하였고, 원왕연 등은 우리나라 의료환경에 적합한 종합병원 입원환자 금연프로 그램의 구축에 관한 연구를 제출하였다. 다학제의 여러 심사 자들이 각 논문 당 3 명이 참여하여 심도있는 심사를 해준 점 도 고맙게 생각한다.

학회지 창간 과정에서 전산심사시스템의 도입과 간행위 원회 운영 등에 미숙한 점도 있었지만 간행위원회 위원 등 여러분들 덕분에 마침내 대한금연학회지를 출범시킬 수 있 게 된 것을 기쁘게 생각한다. 학회지가 적어도 년 2회 금연과 관련된 좋은 논문을 싣고, 금연 관련 연구자들과 활동가들이 관심을 가지고 읽을 수 있도록 내실 있고 꾸준하게 발간되고 발전하기를 희망해본다. 